\title{
PEMBUKTIAN PENGANJUR DALAM TINDAK PIDANA PEMBUNUHAN ANAK
}

\author{
Irene Ulfa \\ iir.recht@yahoo.com \\ Universitas Airlangga
}

\begin{abstract}
The doctrine of inclusion as a basis for expanding the crime can be criminalized by a person who is involved in the realization of a crime. Participation is regulated in Article 55, Article 56 of the Criminal Code and Article 57 of the Criminal Code which means that there are two or more persons who commit a crime. The inclusion of (deelneming) in positive law is that there are two or more persons who commit a crime or in the words of two or more persons participating in a criminal act may be mentioned that a person participates in relation to another person (provided for in Article 55 and 56 of the Criminal Code). In Article 55 paragraph 1 to 2 of the Criminal Code, the Concept of the Occupation can be categorized as those who give or promise something by misusing power or dignity, by violence, threat or misdirection, or by providing opportunities, means or information, deliberately encouraging others to do deeds. The participation of advocates on the crime of child killing can be subject to accountability that has been regulated as Article 343 of the Criminal Code. Article 55 and Article 56 of the Criminal Code there are four forms of participation: a). order to do; b). participate; c). advocates / moves others to do; d). help do or help to do.
\end{abstract}

Keywords: Proof; Advocates; Murder

\begin{abstract}
Abstrak
Ajaran tentang penyertaan sebagai dasar memperluas dapat dipidananya orang yang tersangkut dalam terwujudnya delik. Penyertaan diatur dalam Pasal 55, Pasal 56 KUHP dan Pasal 57 KUHP yang berarti bahwa ada dua orang atau lebih yang melakukan suatu tindak pidana. Penyertaan (deelneming) dalam hukum positif yaitu ada dua orang atau lebih yang melakukan suatu tindak pidana atau dengan perkataan ada dua orang atau lebih mengambil bagian untuk mewujudkan suatu tindak pidana dapat disebutkan bahwa seseorang tersebut turut serta dalam hubungannya dengan orang lain (diatur dalam Pasal 55 dan 56 KUHP). Di dalam Pasal 55 ayat 1 ke 2 KUHP, Konsep Pengajur dapat dikategorikan sebagai mereka yang dengan memberi atau menjanjikan sesuatu dengan menyalahgunakan kekuasaan atau martabat, dengan kekerasan, ancaman atau penyesatan, atau dengan memberi kesempatan, sarana atau keterangan, sengaja menganjurkan orang lain supaya melakukan perbuatan. Keturutsertaan penganjur pada tindak pidana pembunuhan anak dapat dikenakan pertanggungjawaban yang telah diatur sebagaimana Pasal 343 KUHP. Pasal 55 dan Pasal 56 KUHP terdapat empat bentuk keturutsertaan: a). menyuruh melakukan; b). turut serta melakukan; c).penganjur/ menggerakan orang lain untuk melakukan; d).membantu melakukan atau membantu untuk melakukan.
\end{abstract}

Kata Kunci: Pembuktian; Penganjur; Pembunuhan.

\section{Pendahuluan}

Undang-Undang Dasar 1945 menentukan bahwa negara berkewajiban melindungi segenap bangsa Indonesia dan seluruh tumpah darah Indonesia. Perlindungan yang dimaksud meliputi perlindungan masyarakat dari segala macam 
tindak kekerasan. Tak terkecuali anak - anak mendapatkan perlindungan dan perhatian secara khusus dari pemerintah. Pasal 1 angka 5 Undang-Undang Republik Indonesia Nomor 39 Tahun 1999 Tentang Hak Asasi Manusia menerangkan Anak adalah setiap manusia yang berusia dibawah 18 (delapan belas) tahun dan belum menikah, termasuk anak yang masih dalam kandungan apabila hal tersebut adalah demi kepentingannya.

Bahwa hak anak dalam kandungan untuk dapat hidup adakalanya terenggut apabila si ibu tidak menghendaki anak yang dikandungnya dikarenakan beberapa faktor antara lain kehamilan si ibu dikarenakan sebagai korban atas tindak pidana persetubuhan yang dialaminya. Rasa malu, takut apabila kehamilannya diketahui oleh orang lain serta tekanan dalam lingkungan sosial mengakibatkan si ibu nekat melakukan menghilangkan nyawa anaknya baik karena inisiatif dirinya sendiri ataupun anjuran orang lain. Oleh karenanya diperlukan hukum pidana yang berfungsi mengatur kehidupan bermasyarakat. Dimana sifat hukum pidana adalah sebagai "ultimum remidium" dalam penegakkan hukum pidana untuk memberikan efek jera bagi pelaku.

Tindak pidana adalah tindakan yang dinilai melanggar ketentuan KUHP. Maksudnya ialah bilamana ada seseorang melakukan tindakan melanggar hukum maka orang tersebut dapat dikenai salah satu pasal dalam KUHP, adapun yang dimaksud pelanggaran adalah tindakan menurut hukum yang berlaku tidak boleh dilakukannya. Dapat dimengerti apa yang dimaksudkan dengan istilah "tindak pidana" atau dalam bahasa Belanda strafbaar feit yang sebenarnya istilah resmi dalam Strafwetboek atau Kitab Undang-Undang Hukum Pidana yang sekarang berlaku Indonesia, ada istilah dalam bahasa lain yaitu delict. Tindak pidana berarti suatu perbuatan yang pelakunya dapat dikenakan hukuman pidana. Dan pelaku ini dapat dilakukan merupakan "subyek" tindak pidana. ${ }^{1}$

Istilah tindak pidana adalah berasal dari istilah yang dikenal dalam hukum Belanda yaitu "strafbaarfeit". Strafbaarfeit dari dua kata yakni strafbaar dan feit, yang mana strafbaar diterjemahkan dengan dapat dihukum, sedangkan kata feit 
diterjemahkan dengan kenyataan. ${ }^{2}$ Menurut Simons dalam merumuskan strafbaarfeit itu adalah tindakan melanggar hukum yang telah dilakukan sengaja ataupun tidak sengaja oleh seseorang yang dapat dipertanggungjawabkan atas tindakannya dan oleh undang-undang telah dinyatakan sebagai tindakan yang dapat dihukum. ${ }^{3}$

Menurut Pompe straafbaarfeit, secara teoritis dapat dirumuskan sebagai suatu: "Pelanggaran norma atau gangguan terhadap tertib hukum yang dengan sengaja atau tidak sengaja telah dilakukan oleh seorang pelaku, dimana penjatuhan hukuman terhadap pelaku itu adalah penting demi terpeliharanya tertib hukum dan terjaminnya kepentingan umum". Hukum pidana dapat didefinisikan sebagai berikut: aturan hukum yang mengikatkan kepada suatu perbuatan yang memenuhi syarat-syarat tertentu suatu akibat yang berupa pidana (defenisi dari Mezger). Tindak pidana menurut Prof. Moeljatno, menganggap lebih tepat dipergunakan istilah: perbuatan pidana dan pertanggungan jawab dalam hukum pidana, perbuatan itu ialah keadaan yang dibuat oleh seseorang atau barang sesuatu yang dilakukan. Perbuatan ini menunjukkan baik pada akibatnya maupun yang menimbulkan akibat. Jadi mempunyai makna yang abstrak. ${ }^{4}$

Kejahatan terhadap jiwa seseorang yang menimbulkan akibat matinya seseorang merupakan perbuatan yang dilarang dan diancam dengan hukuman oleh undang-undang. Pembunuhan adalah suatu kejahatan yang tidak manusiawi, karena pembunuhan merupakan suatu perbuatan yang mengakibatkan kematian orang lain, yang dilakukan secara sadis.

Dengan demikian, selain telah melakukan tindak pidana, pertanggungjawaban pidana hanya dapat dituntut ketika tindak pidana dilakukan dengan kesalahan. Oleh karena itu, pengkajian mengenai teori pemisahan tindak pidana dan pertanggungjawaban pidana, pertama-tama dilakukan dengan menelusuri penerapan dan perkembangannya dalam putusan pengadilan.

\footnotetext{
${ }^{2}$ Evi Hartanti, Tindak Pidana Korupsi (Sinar Grafika 2005).[5].

${ }^{3}$ ibid.

${ }^{4}$ ibid.[39].
} 


\section{Kualifikasi Penganjuran Dalam Tindak Pidana Pembunuhan Anak}

\section{A. Konsep Penganjuran Dalam Pasal 55 ayat 1 ke 2 KUHP}

\section{Penyertaan (Deelneming) Dalam Tindak Pidana.}

Ajaran tentang penyertaan sebagai dasar memperluas dapat dipidananya orang yang tersangkut dalam terwujudnya delik. Penyertaan diatur dalam Pasal 55, Pasal 56 KUHP dan Pasal 57 KUHP yang berarti bahwa ada dua orang atau lebih yang melakukan suatu tindak pidana. Penyertaan (deelneming) dalam hukum positif yaitu ada dua orang atau lebih yang melakukan suatu tindak pidana atau dengan perkataan ada dua orang atau lebih mengambil bagian untuk mewujudkan suatu tindak pidana dapat disebutkan bahwa seseorang tersebut turut serta dalam hubun gannya dengan orang lain (diatur dalam Pasal 55 dan 56 KUHP). ${ }^{5}$ Menurut Satochid Kartanegara mengartikan Deelneming apabila dalam satu delik tersangkut beberapa orang atau lebih dari satu orang. Menurut doktrin, Deelneming berdasarkan sifatnya terdiri atas: ${ }^{6}$

a. Deelneming yang berdiri sendiri, yakni pertanggung jawaban dari setiap peserta dihargai sendiri-sendiri;

b. Deelneming yang tidak berdiri sendiri, yakni pertanggungjawaban dari peserta yang satu digantunggkan dari perbuatan peserta yang lain.

Kualifikasi pelaku delik berdasarkan Pasal 55 dan Pasal 56 KUHP terbagi dalam 5 (lima) golongan yaitu yang melakukan perbuatan (plegen, dader), yang menyuruh melakukan perbuatan (doen plegen, middelijke dader), yang turut melakukan perbuatan (medeplegen, mededader), yang membujuk supaya perbuatan di lakukan (uitlokken, uitlokker) yang membantu perbuatan (medeplichtig zijn, medeplichtige).

Penyertaan diatur dalam Pasal 55 KUHP yang secara lengkap menyebutkan sebagai berikut:

a. Dipidana sebagai pelaku tindak pidana:

\footnotetext{
${ }^{5}$ Erdianto Effendi, Hukum Pidana Indonesia (Refika Aditama 2011).[174].

6 Satochid Kartanegara, Hukum Pidana Kumpulan Kuliah Bagian Satu (Balai Lektur Mahasiswa).[497-498].
} 
1) Mereka yang melakukan, yang menyuruh melakukan, dan yang turut serta melakukan perbuatan;

2) Mereka yang dengan memberi atau menjanjikan sesuatu dengan menyalahgunakan kekuasaan atau martabat, dengan kekerasan, ancaman atau penyesatan, atau dengan memberi kesempatan, sarana atau keterangan, sengaja menganjurkan orang lain supaya melakukan perbuatan.

b. Terhadap penganjur, hanya perbuatan yang sengaja dianjurkan sajalah yang diperhitungkan, beserta akibat-akibatnya.

Klasifikasi pelaku menurut ketentuan Pasal 55 KUHP adalah:

1. Pelaku (plegen, dader)

Pelaku tindak pidana yang pada hakekatnya memenuhi semua unsur dari tindak pidana. Dalam arti sempit, pelaku adalah mereka yang melakukan tindak pidana. Sedangkan dalam arti luas meliputi keempat klasifikasi pelaku diatas yaitu mereka yang melakukan perbuatan, mereka yang menyuruh melakukan, mereka yang turut serta melakukan dan yang menganjurkan.

2. Menyuruh melakukan (Doenplegen, Medelijke Dader)

Seseorang ingin melakukan suatu tindak pidana, akan tetapi ia tidak melaksanakannya sendiri. Dia menyuruh orang lain untuk melaksanakannya. Dalam penyertaan ini orang yang disuruh tidak akan dipidana, sedang orang yang menyuruhnya dianggap sebagai pelakunya. Dialah yang bertanggungjawab atas peristiwa pidana karena suruhannyalah terjadi suatu tindak pidana.

3. Turut serta melakukan (Medeplegen, Mede Dader)

Mereka yang ikut serta dalam suatu tindak pidana. Terdapat syarat dalam bentuk mereka yang turut serta, antara lain:

a. Adanya kerjasama secara sadar dari setiap peserta tanpa perlu ada kesepakatan, tapi harus ada kesengajaan untuk mencapai hasil berupa tindak pidana.

b. Ada kerja sama pelaksanaan secara fisik untuk melakukan tindak pidana. 


\section{Penganjur (Uitlokker)}

Penganjur sudah dirumuskan dengan jelas secara limitatif pada Pasal 55 ayat 1 ke 2 yaitu mereka yang dengan memberi atau menjanjikan sesuatu dengan menyalahgunakan kekuasaan atau martabat, dengan kekerasan, ancaman atau penyesatan, atau dengan memberi kesempatan, sarana atau keterangan, sengaja menganjurkan orang lain supaya melakukan perbuatan Mereka yang menggerakkan/ menganjurkan/ membujuk yaitu seseorang yang mempunyai kehendak untuk melakukan tindak pidana, tetapi tidak melakukannya sendiri, melainkan menggerakkan orang lain untuk melaksanakan niatnya itu.

Selanjutnya, Pasal 56 KUHP menyebutkan dipidana sebagai pembantu kejahatan:

a. mereka yang sengaja memberi bantuan pada waktu kejahatan dilakukan;

b. mereka yang sengaja memberi kesempatan, sarana atau ke- terangan untuk melakukan kejahatan.

Klasifikasi menurut Pasal 56 KUHP yaitu membantu melakukan mensyaratkan keterlibatan lebih dari satu orang untuk melakukan suatu tindak pidana, sehingga ada orang yang berperan melakukan yaitu pelaku tindak pidana dan ada orang lain yang membantu terlaksananya tindak pidana itu. Menurut ketentuan Pasal 56 KUHP diatas, pembantuan dapat dibedakan berdasarkan waktu diberikannya suatu bantuan terhadap kejahatan, antara lain: a. Apabila bantuan diberikan pada saat kejahatan dilakukan, tidak dibatasi jenis bantuannya dalam suatu kejahatan dapat dipidana;

b. Apabila bantuan diberikan sebelum kejahatan dilakukan, jenis bantuan dibatasi yaitu kesempatan, sarana, dan keterangan.

Tentang pertanggungjawaban pembantu tindak pidana, ancaman pidananya termuat dalam Pasal 57 KUHP, pertanggungjawaban pembantu dibatasi hanya terhadap tindak pidana yang dibantunya saja. Apabila dalam suatu peristiwa ternyata terjadi tindak pidana yang berlebih, maka tindak pidana yang lebih tersebut bukan merupakan tanggung jawab pembantu, 
kecuali tindak pidana tersebut merupakan akibat langsung dari perbuatan yang dibantunya.

Menurut teori obyektif (de obyectieve deelnenings theorie), antara pembantuan dengan turut serta dibedakan menurut sifat perbuatannya, yakni apabila seseorang melakukan perbuatan yang menurut sifatnya adalah merupakan perbuatan yang dilarang undang-undang, maka orang tersebut melakukan dalam bentuk "turut serta". Sedangkan apabila orang tersebut perbuatannya tidak bersifat tindak pidana, dia dianggap melakukan "pembantuan". Sedangkan menurut teori subyektif (de subyectieve deelnemings theorie), perbedaannya terletak pada kehendak pelaku, dalam hal turut serta pelaku berkehendak terjadinya tindak pidana, sedangkan dalam pembantuan kehendak pelaku ditujukan pada memberi bantuan kepada pelaku yang melakukan tindak pidana, artinya dalam hal pembantuan tidak mempunyai tujuan dan kepentingan melakukan tindak pidana berdiri sendiri, sedangkan dalam turut serta tujuan dan kepentingan pelakukan untuk melakukan tindak pidana berdiri sendiri.

Perbedaan antara "pembantuan" dengan "menggerakkan", dapat dibedakan melalui kehendak dari pelaku. Dalam bentuk "penggerakkan" kehendak untuk melakukan tindak pidana baru timbul setelah ada daya upaya dari orang yang menggerakkan. Jadi dimulai oleh penggerak dengan memberi daya upaya, barulah orang yang dapat digerakkan mempunyai kehendak untuk melakukan tindak pidana. Dalam hal "pembantuan", dimana dari semula dalam diri pelaku sudah ada kehendak untuk melakukan tindak pidana. Pembantuan baru kemudian diberikan yang dapat berupa sarana, kesempatan dan keterangan.

Dari ketentuan Pasal 55 ayat 1 ke 2 KUHP, pada frasa kalimat "sengaja menganjurkan orang lain supaya melakukan perbuatan", maka untuk dikategorikan sebagai penganjur, seseorang harus memenuhi 2 (dua) syarat, yaitu pertama adanya niat dan yang kedua ada kehendak menggerakkan orang lain untuk melakukan perbuatan tertentu yang dimaksud oleh penganjur. 
Akibat dari anjuran orang yang menganjurkan adalah tergeraknya orang yang dianjurkan untuk melakukan perbuatan. Oleh karena itu, anjuran penganjur harus tegas dan jelas sehingga dapat ditafsirkan oleh pelaku.

\section{Konsep Penganjur Dalam Tindak Pidana Pembunuhan Anak}

\section{a. Makna Penganjur Dalam KUHP}

Di dalam Pasal 55 ayat 1 ke 2 KUHP, Konsep Pengajur dapat dikategorikan sebagai mereka yang dengan memberi atau menjanjikan sesuatu dengan menyalahgunakan kekuasaan atau martabat, dengan kekerasan, ancaman atau penyesatan, atau dengan memberi kesempatan, sarana atau keterangan, sengaja menganjurkan orang lain supaya melakukan perbuatan. Menurut Adami Chazawi rumusan undang-undang tersebut terdiri dari 2 (dua) unsur, yaitu: ${ }^{7}$

1. Unsur obyektif, yang terdiri dari :

a) Unsur perbuatan ialah menganjurkan orang lain melakukan suatu perbuatan, tindak pidana dengan cara:

1. Memberikan sesuatu;

2. Menjanjikan sesuatu;

3. Menyalahgunakan kekuasaan;

4. Dengan kekerasaan;

5. Dengan ancaman;

6. Dengan penyesatan.

b) Unsur subyektif, adalah kesengajaan

Menurut Adam Chazwi syarat untuk menganjurkan adalah: ${ }^{8}$

1. Kesengajaan si penganjur, yang harus ditujukan kepada 4 (empat) hal yaitu:

a. Ditujukan pada digunakan upaya-upaya penganjuran;

b. Ditujukan pada mewujudkan perbuatan menganjurkan beserta akibatnya;

\footnotetext{
${ }^{7}$ Adami Chazawi, Pelajaran Hukum Pidana: Stelsel Pidana, Tindak Pidana, Teori- Teori Pemidanaan Dan Batas Berlakunya Hukum Pidana, Raja Grafindo Persada (Raja Grafindo Persada 2005).

${ }^{8}$ Adami Chazawi, Pelajaran Hukum Pidana: Stelsel Pidana, Tindak Pidana, Teori-Teori Pemidanaan Dan Batas Berlakunya Hukum Pidana (Raja Grafindo Persada 2005).[113].
} 
c. Ditujukan pada orang lain untuk melakukan perbuatan apa yang dianjurkan;

d. Ditujukan pada orang lain yang dapat dipertanggungjawabkan atau dipidana.

2. Dalam melakukan perbuatan menganjurkan, harus menggunakan cara-cara menganjurkan sebagai mana yang ditentukan dalam Pasal 55 ayat 1 angka 2;

3. Terbentuknya kehendak yang dianjurkan (pelaksana) untuk melakukan tindak pidana sesuai dengan apa yang dianjurkan adalah disebabkan langsung oleh digunakannya upaya-upaya penganjuran oleh si penganjur (adanya psychische causaliteit);

4. Orang yang dianjurkan (pelaksana) telah melaksanakan tindak pidana sesuai dengan yang dianjurkan (boleh pelaksanaan itu sesuai atau sebatas percobaan);

5. Orang yang dianjurkan adalah orang yang mampu bertanggungjawab.

Berdasarkan dari hal tersebut diatas Nampak ciri dari penganjur ialah bahwa ia sendiri yang menentukan kehendak yang jahat, sehingga timbullah perbuatan yang dapat dihukum. Orang yang sengaja membujuk, melakukan tindak pidana tersebut juga auctor intellectualis, seperti pada orang yang menyuruh melakukan tindak pidana tidak mewujudkan tindak pidana secara materil tetapi melalui orang lain. ${ }^{9}$

Pertanggungjawaban penganjur dalam sistem penyertaan di Indonesia, sebagaimana diketahui bahwa penganjuran (Uitlokker) merupakan bentuk penyertaan yang berdiri sendiri, hal ini berarti bahwa berdasarkan daya upaya yang dilakukan oleh seorang itu, oleh penganjur tidak boleh dilakukan suatu delik yang selesai penuh (Voltooid), bahkan apabila oleh si penganjur dilakukan perbuatan percobaan terhadap suatu delik, maka sipenganjur tersebut telah dapat dipertanggungjawabkan untuk dipidana sama dengan pembuat atau pelaku. ${ }^{10}$

\section{b. Konsep Pembunuhan Anak di Dalam Hukum Indonesia}

Pengertian anak menurut Undang-undang Nomor 35 Tahun 2014 Tentang

\footnotetext{
9 Moeljatno, Hukum Pidana Delik-Delik Penyertaan (Bina Aksara 1983).[52].

${ }^{10}$ Aruan Sakidjo dan Bambang Poernomo, Hukum Pidana Dasar Aturan Umum Hukum Pidana Kodifikasi (Ghalia Indonesia 1990).[151-152].
} 
Perubahan atas Undang-undang Nomor 23 Tahun 2002 Tentang perlindungan anak adalah seseorang yang belum berusia 18 (delapan belas) tahun, termasuk anak yang masih dalam kandungan, sedangkan pengertian anak korban menurut Pasal 1 angka 4 Undang-undang Nomor 11 Tahun 2012 Tentang Sistem Peradilan Anak adalah anak yang menjadi korban tindak pidana yang selanjutnya disebut anak korban adalah anak yang belum berumur 18 (delapan belas) tahun yang mengalami penderitaan fisik, mental, dan/atau kerugian ekonomi yang disebabkan oleh tindak pidana. Itu berarti semenjak seorang anak dalam kandungan sampai belum berusia 18 (delapan belas) tahun telah mendapat perlindungan hukum. Sehingga bagi pelaku tindak pidana terhadap anak dapat dijatuhi pidana sesuai kadar kejahatannya.

Pengertian Anak Menurut KUHP diatur dalam Pasal 45 KUHP adalah anak yang umurnya belum mencapai 16 (enam belas) tahun. KUHP melakukan pembedaan antara anak dan janin yang masih dalam kandungan. Pembunuhan dalam undang-undang dinyatakan sebagai kesengajaan menghilangkan nyawa, yang mana adanya niatan dari pelaku untuk menghilangkan nyawa orang lain, pelaku harus melakukan suatu tindakan atau rangkaian tindakan yang berakibat meninggalnya orang lain. Tindak pidana pembunuhan merupkan delik materiil, yang artinya delik yang dirumuskan secara materiil, yakni delik yang baru dapat dianggap sebagai telah selesai dilakukan oleh pelakunya dengan timbulnya akibat yang dilarang atau yang tidak dikehendaki oleh undang- undang. ${ }^{11}$

Dalam Undang-undang Nomor 35 Tahun 2014 Tentang Perubahan atas Undang-Undang Nomor 23 Tahun 2002 Tentang Perlindungan Anak, tidak menerangkan secara khusus tindakan pembunuhan anak, namun merupakan perbuatan kekerasan terhadap anak yang mengakibatkan anak mati. Jadi tidak diperlukan apakah niat awal pelaku adalah untuk membunuh atau tidak. Dalam pasal ini hanya mengedepankan kekerasan terhadap anak. Dalam artian

${ }^{11}$ Lamintang, Dasar-Dasar Hukum Pidana Indonesia (Sinar Grafika).[202]. 
niatan untuk membunuh anak tidak perlu dibuktikan asalkan pelaku telah melakukan kekerasan, maka pelaku dapat dipidana dengan pasal ini.

Sedang didalam KUHP pembunuhan anak ditur dalam pasal tersendiri yang tercantum dalam KUHP pada Bab XIX Kejahatan Terhadap Nyawa. Ketentuan-ketentuan dalam Bab XIX KUHP yang relevan dengan pembunuhan anak yakni:

\section{Pasal 341 KUHP}

Seorang ibu yang karena takut akan ketahuan melahirkan anak, pada saat anak dilahirkan atau tidak lama kemudian, dengan sengaja merampas nyawa anaknya, diancam karena membunuh anak sendiri, dengan pidana penjara.

\section{Pasal 342 KUHP}

Seorang ibu yang untuk melaksanakan niat yang ditentukan karena takut akan ketahuan bahwa ia akan melahirkan anak pada saat anak dilahirkan atau tidak lama kemudian merampas nyawa anaknya, diancam karena melakukan pembunuhan anak sendiri dengan rencana.

\section{Pasal 343 KUHP}

Kejahatan yang diterangkan dalam Pasal 341 dan 342 KUHP dipandang, bagi orang lain yang turut serta melakukan, sebagai pembunuhan atau pembunuhan rencana.

Unsur subyektif dari pasal-pasal tersebut adalah:

a) dengan sengaja;

b) takut akan ketahuan melahirkan anak.

Unsur obyektif:

a) seorang ibu;

b) pada saat anak dilahirkan atau tidak lama kemudian;

c) merampas nyawa anaknya.

Sedang apabila perbuatan tersebut direncanakan terlebih dahulu, unsur obyektifnya:

a) seorang ibu;

b) yang untuk melaksanakan niat yang ditentukan;

c) pada saat anak dilahirkan atau tidak lama kemudian;

d) merampas nyawa anaknya. 
Pasal 341 KUHP dan 342 KUHP, haruslah dibuktikan adanya kesengajaaan yang dan niat awal dari seorang ibu, yang disebabkan adanya kekuatiran dari pelaku, bahwa ia akan menjadi malu, dikucilkan, dimarahi, dan sebagainya yang mana anak yang dilahirkan tersebut adalah hasil hubungan diluar penikahan.

\section{B. Pertanggungjawaban Pidana Penganjur Pembuhunan Anak}

\section{Tindak Pidana Pembunuhan Anak}

Istilah tindak pidana berasal dari istilah yang dikenal dalam hukum pidana Belanda yaitu stafbaar feit. Walaupun istilah ini terdapat dalam $W v S$ Belanda dengan demikian juga $W v S$ Hindia Belanda (KUHP), tetapi tidak ada penjelasan resmi tentang apa yang dimaksud dengan stafbaar feit itu. Karena itu para ahli hukum berusaha untuk memberi arti dan isi dari istilah itu. Tetapi sampai kini belum ada keseragaman pendapat.

Istilah stafbaar feit atau disebut sebagai delict (delik) diterjemahkan ke dalam bahasa indonesia dengan berbagai istilah Moeljatno dan Roeslan Saleh cenderung menterjemahkan dengan istilah perbuatan pidana. ${ }^{12}$ Tresna, E. Utrect menterjemahkan dengan istilah peristiwa pidana, sedangkan Soedarto dan berbagai Undang-undang Hukum Pidana Khusus menggunakan istilah tindak pidana. Pengertian tindak pidana oleh beberapa ahli:

1. Moeljatno, menggunakan istilah perbuatan pidana sebagai perbuatan yang dilarang oleh suatu aturan hukum larangan mana disertai ancaman (sanksi) yang berupa pidana tertentu, bagi barang siapa yang melanggar larangan tersebut. ${ }^{13}$

2. R. Tresna, menyatakan bahwa peristiwa pidana itu adalah sesuatu perbuatan atau rangkaian perbuatan manusia, yang bertentangan dengan Undangundang atau peraturan perundang-undangan lainnya, terhadap perbuatan

\footnotetext{
12 Aloysius Wisnubroto, Teknis Persidangan Pidana (Universitas Atma Jaya 2009).[1].

13 Moeljatno, Loc.Cit.
} 
mana diadakan tindakan penghukuman. ${ }^{14}$

Setiap Tindak Pidana yang tercantum dalam Kitab Undang-undang Hukum Pidana (KUHP) pada umumnya dapat dijabarkan ke dalam unsur-unsur yang pada dasarnya dibagi menjadi dua macam unsur, yakni unsur-unsur subyektif dan unsur-unsur obyektif. Unsur-unsur subyektif adalah unsur-unsur yang melekat pada diri si pelaku atau yang berhubungan dengan diri si pelaku, dan termasuk ke dalamnya yaitu segala sesuatu yang terkandung di dalam hatinya.

Unsur-unsur obyektif adalah unsur-unsur yang ada hubungannya dengan keadaan-keadaan, yaitu di dalam keadaan-keadaan mana tindakan-tindakan dari si pelaku itu harus dilakukan. Lebih lanjut Moeljatno menjelaskan, bahwa "Tindak pidana adalah perbuatan yang dilarang oleh suatu aturan hukum, larangan mana disertai ancaman (sanksi) yang berupa pidana tertentu bagi barang siapa yang melanggar larangan tersebut". ${ }^{15}$

Untuk mengetahui adanya tindak pidana, maka pada umumnya dirumuskan dalam peraturan perundang-undangan pidana tentang perbuatanperbuatan yang dilarang dan disertai dengan sanksi. Dalam rumusan tersebut ditentukan beberapa unsur atau syarat yang menjadi ciri atau sifat khas dari larangan tadi sehingga dengan jelas dapat dibedakan dari perbuatan lain yang tidak dilarang. Perbuatan pidana menunjuk kepada sifat perbuatannya saja, yaitu dapat dilarang dengan ancaman pidana kalau dilanggar. ${ }^{16}$

Sedangkan yang dimaksud sebagai unsur Subyektif adalah orang yang mampu bertanggungjawabdanadanyakesalahan(dollus atau culpa). Perbuatan harus dilakukan dengan kesalahan. Kesalahan ini dapat berhubungan dengan akibat dari perbuatan atau dengan keadaan mana perbuatan itu dilakukan. ${ }^{17}$

\footnotetext{
${ }^{14}$ Chazawi, Pelajaran Hukum Pidana: Stelsel Pidana, Tindak Pidana, Teori- Teori Pemidanaan Dan Batas Berlakunya Hukum Pidana, Raja Grafindo Persada.[75].

${ }^{15}$ Moeljatno, Azaz-Azaz Hukum Pidana (Modul untuk Diklat Pendidikan dan Pelatihan Pembentukan Jaksa (PPPJ) 2010).[33].

${ }^{16}$ ibid. [34].

17 ibid. [35].
} 


\section{Pertanggungjawaban Pidana}

Di dalam KUHP, tidak secara jelas mendefinisikan yang dimaksud dengan pertanggungjawaban Pidana, akan tetapi Para sarjana hukum telah berusaha meneliti dan menyimpulkan dalam berbagai pendapat para ahli, yaitu: ${ }^{18}$

a. Van Hammel

Kemampuan bertanggungjawab adalah suatu keadaan normalitas psychis dan kematangan (kecerdasan) yang membawa tiga kemampuan, yaitu:

1) Mampu untuk mengerti nilai dari akibat-akibat perbuatannya sendiri;

2) Mampu untuk menyadari bahwa perbuatannya itu menurut pandangan masyarakat tidak diperbolehkan;

3) Mampu untuk menentukan kehendaknya atas perbuatan-perbuatannya itu.

b. Simmons

Kemampuan bertanggungjawab dapat diartikan sebagai suatu keadaan psychish sedemikian, yang membenarkan adanya penerapan sesuatu upaya pemidanaan, baik dilihat dalam sudut umum maupun dari orangnya. Seorang dapat dipertanggungjawabkan apabila :

1) Ia mampu untuk mengetahui atau menyadari bahwa perbuatannya bertentangan dengan hukum.

2) Ia dapat menentukan kehendaknya sesuai dengan kesadaran tersebut.

Merumuskan pertanggungjawaban pidana secara negatif, terutama berhubungan dengan fungsi represif hukum pidana. Dalam hal ini, dipertanggungjawabakannya seseorang dalam hukum pidana berarti dipidana. Dengan demikian, konsep pertanggungjawaban pidana merupakan syaratsyarat yang diperlukan untuk mengenakan pidana terhadap pembuat tindak pidana. Sementara itu, berpangkal tolak pada gagasan monodualistik (daad en dader strafrecht), proses wajar (due proces) penentuan pertanggungjawaban pidana, bukan hanya dilakukan dengan memerhatikan kepentingan

\footnotetext{
${ }^{18}$ Tri Andrisman, Hukum Pidana Asas-Asas Dan Dasar Aturan Umum Hukum Pidana Indonesia (Universitas Lampung 2009).[97].
} 
masyarakat, tetapi juga kepentingan pembuatnya itu sendiri. Proses tersebut bergantung pada dapat dipenuhinya syarat dan keadaan dapat dicelannya pembuat tindak pidana, sehingga sah jika dijatuhi pidana. Menurut Galligan apabila persyaratan ini diabaikan dan tidak tampak keadaan minimal yang menunjukan pembuat dapat dicela, maka hukum dan institusinya telah gagal memenuhi fungsinya. ${ }^{19}$

Moeljatno, dalam berbagai tulisannya pernah mengatakan bahwa perbuatan pidana dapat disamakan dengan Criminal act. Beliau menolak dengan tegas untuk menggunakan istilah tindak pidana sebagai pengganti istilah Strafbaar feit atau delict. ${ }^{20}$ Senada dengan pendapat Moeljatno, Roeslan Saleh juga mengatakan bahwa perbuatan pidana itu dapat disamakan dengan criminal act, jadi berbeda dengan istilah Strafbaar feit yang meliputi pertanggungjawaban pidana. Criminal act menurutnya berarti kelakuan dan akibat, yang lazim disebut dengan actu reus. Perbuatan pidana (criminal act) harus dibedakan dengan pertanggung jawaban pidana (criminal responsibility). ${ }^{21}$ Oleh karena itu pengertian perbuatan pidana tidak meliputi pertanggung jawaban pidana.

Unsur perbuatan pidana adalah sifat melawan hukumnya perbuatan, sedangkan unsur pertanggungjawaban pidana adalah bentuk-bentuk kesalahan yang terdiri dari kesengajaan (dolus) dan kealpaan (culpa) serta tidak adanya alasan pemaaf. Alasan pemaaf yaitu alasan alasan yang menghapuskan kesalahan dari terdakwa. Adapun asas dari pertanggung jawaban pidana adalah "tidak dipidana apabila tidak ada kesalahan". Ini berarti, bahwa kalau ada alasan pemaaf, terdakwa harus dilepas dari tuntutan hukum (ontslag van rechtsvervolging).

\footnotetext{
${ }^{19}$ Chairul Huda, Dari Tiada Pidana Tanpa Kesalahan Menuju Kepada Tiada Pertanggungjawaban Pidana Tanpa Kesalahan : Tinjauan Kritis Terhadap Teori Pemisahan Tindak Pidana Dan Pertanggungjawaban Pidana (Cetakan I, Kencana 2006).[62].

${ }^{20}$ Moeljatno, Pengantar Ilmu Hukum Pidana (1983).[31].

${ }^{21}$ Roeslan Saleh, Perbuatan Pidana Dan Pertanggung Jawaban Pidana (Cetakan Ke, Aksara Baru 1981).[150].
} 
Roeslan Saleh lebih lanjut menamakan kesengajaan dan kealpaan itu sebagai bentuk-bentuk kesalahan. "Untuk menentukan ada tidaknya kesalahan, maka yang ditinjau adalah sifat-sifat dari orang yang melakukan perbuatan tersebut. Sifat-sifatnya ini dilihat pada saat dia melakukan perbuatan pidana." 22 Lebih lanjut, Roeslan Saleh menamakan kesengajaan dan kealpaan itu sebagai bentuk-bentuk kesalahan. ${ }^{e}$ Untuk menentukan ada tidaknya kesalahan, maka yang ditinjau adalah sifat-sifat dari orang yang melakukan perbuatan tersebut. Sifat-sifatnya ini dilihat pada saat dia melakukan perbuatan pidana". ${ }^{23}$ Sifat melawan hukum dari pada perbuatan pidana adalah bagian dari Ilmu Hukum Pidana, demikian pendapat dari Roeslan Saleh. Beliau menambahkan bahwa:

"Bersifat melawan hukum berarti bertentangan dengan hukum, yaitu lebih luas dari pada bertentangan dengan undang-undang. Selain dari pada peraturan undang-undang disini haruslah diperhatikan aturanaturan yang tidak tertulis. Adapun asas daripada perbuatan pidana adalah asas legalitas, yang dimuat dalam Pasal 1 ayat 1 KUHP. Seperti telah dikemukakan dimuka, bahwa sifat melawan hukumnya perbuatan, berarti tidak ada alasan pembenar. Alasan pembenar inilah yang menghapuskan sifat melawan hukumnya perbuatan". ${ }^{24}$

Dipidananya seseorang tidaklah cukup apabila orang itu telah melakukan perbuatan yang bertentangan dengan hukum atau bersifat melawan hukum. Jadi meskipun perbuatannya memenuhi rumusan delik dalam undang-undang dan tidak dibenarkan, hal tersebut belum memenuhi syarat untuk penjatuhan pidana. Untuk pemidanaan masih perlu adanya syarat, yaitu bahwa orang yang melakukan perbuatan itu mempunyai kesalahan atau bersalah (subjective guilt). Di sini berlaku apa yang disebut asas "Tiada Pidana Tanpa Kesalahan" (Keine Strafe ohne Schuld atau Geen straf zonder schuld atau Nulla Poena Sine Culpa ("culpa" di sini dalam arti luas, meliputi juga kesengajaan). Asas ini tidak tercantum dalam KUHP Indonesia atau dalam peraturan lain, namun berlakunya

\footnotetext{
${ }^{22}$ ibid.

${ }^{23}$ ibid.

${ }^{24}$ Roeslan Saleh, Sifat Melawan Hukum Dari Perbuatan Pidana (Cetakan Ke, Aksara Baru 1981).[32].
} 
asas tersebut sekarang tidak diragukan. Akan bertentangan dengan rasa keadilan, apabila ada orang yang dijatuhi pidana padahal ia sangat sekali tidak bersalah.

Mengenai unsur kesengajaan Moeljatno menggunakan teori pengetahuan atau membayangkan. Alasannya adalah:

"Karena dalam kehendak dengan sendirinya diliputi pengetahuan. Sebab untuk menghendaki sesuatu, orang lebih dahulu sudah harus mempunyai pengetahuan gambaran) tentang sesuatu itu. Tapi apa yang diketahui seseorang belum tentu saja dikehendaki olehnya. Lagi pula kehendak merupakan arah, maksud atau tujuan, hal mana berhubungan dengan motif(alasan pendorong untuk berbuat) dan tujuan perbuatannya. Konsekuensinya ialah, bahwa ia menentukan sesuatu perbuatan yang dikehendaki oleh terdakwa, maka (1) harus dibuktikan bahwa perbuatan itu sesuai dengan motifnya untuk berbuat dan tujuan yang hendak dicapai; (2) antara motif, perbuatan dan tujuan harus ada hubungan kausal dalam batin terdakwa." ${ }^{25}$

Dalam hal ini pembuktian lebih singkat karena hanya berhubungan dengan unsur-unsur perbuatan yang dilakukannya saja. tidak ada hubungan kausal antara motif dengan perbuatan. Dalam perkembangannya kemudian, secara teoritis bentuk kesalahan berupa kesengajaan itu dibedakan menjadi tiga corak, yaitu kesengajaan sebagai maksud, kesengajaan dengan sadar kepastian dan, kesengajaan dengan sadar kemungkinan (dolus eventualis).

\section{Pertanggungjawaban Penganjur Pembunuhan Anak}

Keturutsertaan penganjur pada tindak pidana pembunuhan anak dapat dikenakan pertanggungjawaban yang telah diatur sebagaimana Pasal 343 KUHP. Pasal 55 dan Pasal 56 KUHP terdapat empat bentuk keturutsertaan:

a. menyuruh melakukan;

b. turut serta melakukan;

c. penganjur/ menggerakan orang lain untuk melakukan;

d. membantu melakukan atau membantu untuk melakukan.

${ }^{25}$ Moeljatno, Op.Cit.[172-173]. 
Sebagaimana kualifikasi bentuk keturutsertaan tersebut, Lamintang menerangkan yang dimaksud deelnemen didalam rumusan Pasal 343 KUHP itu bukan turut serta melakukan melainkan turut serta dengan salah satu cara yang telah disebutkan diatas. ${ }^{26}$ Kejahatan yang diterangkan dalam Pasal 341 dan 342 KUHP dipandang, bagi orang lain yang turut serta melakukan, sebagai pembunuhan atau pembunuhan rencana.

Menurut Prof. Van Hattum, dalam peradilan karena keturutsertaan dalam pembunuhan dengan direncanakan lebih dulu itu harus terbukti bahwa orang yang turut serta dalam pembunuhan dengan direncanakan lebih dulu tersebut memenuhi unsur perencanaan lebih dulu seperti yang disyaratkan dalam $340 \mathrm{KUHP}^{27}$

Berdasarkan pendapat tersebut nampak apabila orang yang telah turut serta dalam pembunuhan anak bukan dituntut karena pembunuhan melainkan karena keikutsertaannya. Sehingga terhadap pengganjur pembunuhan anak dapat dikenakan pembunuhan anak atas apa yang dianjurkannya sebagaimana Pasal 343 KUHP.

Dalam hal terjadi delik penyertaan sebagai penganjur, maka harus ada unsur dilakukan secara bersama-sama, dan adanya unsur kesamaan niat, sehingga pelaku yang bertemu dengan satu atau beberapa orang penganjur tidak serta merta dapat dikategorikan sebagai turut serta penganjur. Hal tersebut berkaitan dengan pembuktian dari rangkaian peristiwa, sehingga ada hubungan sebab-akibat antara ucapan-ucapan penganjur dengan dilaksanakannya perbuatan yang dianjurkan dan akibat dari perbuatan yang dianjurkan.

Bahwa untuk terhadap penganjur pembunuhan anak dapat dipidana apabila memenuhi syarat kemampuan bertanggung jawab. Pasal KUHP yang berkaitan dengan pertanggungjawaban pidana ialah Pasal 44 KUHP yang menyatakan bahwa: "Barang siapa melakukan perbuatan yang tidak

\footnotetext{
${ }^{26}$ Lamintang. Op.Cit. [556].
}

${ }^{27}$ ibid. 
dapat d ipertanggungjawabkan kepadanya, karena jiwanya cacat dalam tumbuhnya atau jiwa yang terganggu karena penyakit tidak dipidana”.

Penghapusan pidana dapat menyangkut perbuatan atau pembuatnya, maka dibedakan 2 (dua) jenis alasan penghapus pidana, yaitu:

1. Alasan pembenar;

2. Alasan pemaaf atau alasan penghapus kesalahan.

Bahwa berdasarkan hal tersebut diatas nampak apabila konsep penganjur tidak dapat be rdiri sendiri, dimana harus ada tindak pidana materiil terlebih dahulu. Sehingga si penganjur dapat dipidana apabila telah ada tindak pidana yang dilakukan oleh pelaku utama, terlepas apakah tindak pidana tersebut telah dilaksanakan atau gagal dilaksanakan. Sehingga sebagaimana Pasal 55 ayat 1 ke-2 KUHP, dengan memberikan anjuran kepada seseorang untuk melakukan tindak pidana, dengan memberi atau menjanjikan sesuatu dengan menyalahgunakan kekuasaan atau martabat, dengan kekerasan, ancaman atau penyesatan, atau dengan memberi kesempatan, sarana atau keterangan, sengaja menganjurkan orang lain supaya melakukan perbuatan tindak pidana, maka penganjur dapat dijatuhi hukuman pidana.

\section{Pembuktian penganjur berdasarkan KUHAP di dalam pembunuhan anak}

\section{A. Hukum pembuktian dalam hukum acara pidana}

\section{Teori pembuktian dalam hukum acara pidana}

Tujuan dari Hukum Acara Pidana adalah un tuk mencari dan mendapatkan suatu kebenaran yang bersifat materiil, yakni kebenaran dari suatu tindak pidana dengan menerapkan ketentuan Hukum Acara Pidana secara obyektif dengan tujuan untuk mencari siapakah pelaku yang dimintai pertanggungjawaban pidana dan berdasarkan Putusan dari Pengadilan guna menemukan dan seseorang terbukti melakukan tindak pidana dan apakah orang yang didakwakan itu dapat dipersalahkan. 
Menurut Teguh Samudera, ${ }^{28}$ bahwa masalah pembuktian penting sekali diketahui oleh seluruh masyarakat masyarakat dan oleh karena itu perlu pula untuk disebar luaskan agar masyarakat lebih jelas memahami masalah pembuktian dengan alasan pertimbangan sebagai berikut :

a. Pada dasarnya pembuktian adalah merupakan bagian yang penting dalam hukum acara;

b. Baik dalam mengadili perkara hakim selalu memerlukan pembuktian.

c. Dengan diselesaikannnya suatu perkara melalui Pengadilan maka akan dicapai suatu penyelesaian yang pasti berdasarkan alat-alat pembuktian;

d. Karena dengan pembuktian dimaksudkan akan dapat dicapai suatu kebenaran yang sesungguhnya yaitu kebenaran dari hubungan hukum pihak-pihak yang berperkara;

e. Dan dengan jalan pembuktian maka akan dapat diketahui siapa sebenarnya yang benar;

f. Dan dengan adanya pembuktian maka akan dapat dijamin adanya perlindungan terhadap hak-hak asasi para pihak yang berperkara secara seimbang;

g. Oleh karena dengan pembuktian dapat memberikan gambaran bahwa pemeriksaan suatu perkara adalah pemeriksaan yang benar menurut hukum;

h. Adanya alat alat pembuktian itu dapat menjamin bahwa hakim dalam melakukan pembuktian tidak mengada-ada karena telah ditentukan dalam undang-undang;

i. Adalah suatu kenyataan yang tidak dapat dipungkiri bahwa masih ada sarjana hukum yang belum tahu bagaimana cara membuktikan suatu hal yang didalilkan.

Menurut Van Bemmelen dalam bukunya "Strafordering Leerbook Van Het Nederlandsch Straf Procesrecht" (Undang-Undang di Belanda yang memuat tentang Hukum Acara Pidana) bahwa yang terpenting dalam Hukum Acara Pidana adalah mencari dan memperoleh Kebenaran. Sementara itu, menurut doktrin (pendapat para ahli Hukum) bahwa tujuan Hukum Acara Pidana adalah:

1) Mencari dan menemukan kebenaran materiil;

2) Memperoleh putusan Hakim; dan

3) Melaksanakan putusan Hakim.

Dari ketiga fungsi diatas, yang paling penting karena menjadi tumpuan kedua fungsi berikutnya, ialah "mencari kebenaran". Setelah

\footnotetext{
${ }^{28}$ Teguh Samudera, Hukum Pembuktian Dalam Acara Perdata (PT Alumni 2004).[10].
} 
menemukan kebenaran yang diperoleh melalui alat bukti dan bahan bukti itulah, hakim akan sampai kepada putusan (yang seharusnya adil dan tepat), karena kemudian dilaksanakan oleh jaksa. Jadi, tujuan hukum acara pidana mencari kebenaran yang bertujuan mencapai suatu ketertiban, ketentraman, kedamaian, keadilan, dan kesejahteraan dalam masyarakat. Jaksa kemudian mendakwakan pelaku suatu kejahatan hukum, dan kemudian meminta pemeriksaan dan putusan pemgadilan guna menemukan apakah bukti bahwa suatu tindak pidana telah dilakukan dan apakah orang yang di dakwakan itu dapat dipersalahkan.

Pembuktian adalah perbuatan membuktikan. Pembuktian adalah suatu proses menemukan bagaimana alat-alat bukti tersebut dipergunakan, diajukan ataupun dipertahankan, sesuatu hukum acara yang berlaku. Sementara itu membuktikan berarti memperlihatkan bukti atau meyakinkan dengan bukti. Menurut Van Bemmelen adalah memberikan kepastian yang layak menurut akal (redelijk) tentang:

a. apakah hal yang tertentu itu sungguh-sungguh terjadi;

b. apa sebabnya demikian halnya.

Pembuktian menjadi bagian terpenting dari keseluruhan proses pemeriksaan perkara perdata maupun perkara pidana dalam persidangan. Tujuan hukum acara perdata ataupun hukum acara pidana adalah mencari kebenaran. Perbedaannya dalam perkara perdata dan tujuan yang hendak dicapai ialah kebenaran Perbedaannya dalam perkara perdata dan tujuan yang hendak dicapai ialah kebenaran formal sementara perkara pidana mencari kebenaran sejati atau kebenaran materiil. Mencari kebenaran sejati ini sangat luas, karena itu dalam KUHAP terdapat empat tahap dalam mencari kebenaran sejati yakni melalui:

a. Penyidikan;

b. Penuntutan;

c. Pemeriksaan di persidangan;

d. Pelaksanaan, pengamatan, dan pengawasan.

Dalam kedudukannya sebagai instrumen hukum publik yang mendukung pelaksanaan dan penerapan ketentuan hukum pidana materiil 
maka Undang-undang Nomor 8 Tahun 1981 Tentang Kitab Undangundang Hukum Acara Pidana (KUHAP) telah memiliki rumusan sistem pembuktian tersendiri. Adapun rumusan sistem pembuktian tersebut tentunya untuk mendukung tujuan dari hukum acara pidana, yaitu untuk mencari dan memperoleh kebenaran materiil. ${ }^{29}$

Pembuktian adalah ketentuan-ketentuan yang berisi penggarisan dan pedoman tentang cara-cara yang dibenarkan undang-undang membuktikan kesalahan yang didakwakan kepada terdakwa ${ }^{30}$ Dengan tercapainya kebenaran materiil maka akan tercapai pula tujuan akhir hukum acara pidana, yaitu untuk mencapai suatu ketertiban, ketentraman, keadilan dan kesejahteraan dalam masyarakat. ${ }^{31}$ Ditinjau dari perspektif sistem peradilan pidana maka perihal pembuktian merupakan hal yang sangat determinan bagi setiap pihak yang terlibat secara langsung dalam proses pemeriksaan perkara pidana, khususnya dalam hal menilai terbukti atau tidak terbuktinya kesalahan yang didakwakan kepada terdakwa. ${ }^{32}$

Tujuan dari acara pidana adalah untuk menentukan kebenaran, dan berdasarkan atas kebenaran itu akan ditetapkan suatu putusan hakim yang melaksanakan suatu peraturan hukum pidana. Pembuktian tentang benar tidaknya terdakwa melakukan perbuatan yang didakwakan, merupakan bagian yang terpenting acara pidana. Bagaimana akibatnya jika seseorang yang didakwakan berdasarkan alat bukti yang ada disertai keyakinan hakim, padahal tidak benar. Maka soal yang amat penting bagaimana hakim dapat menetapkan hal adanya kebenaran itu, soal ini adalah mengenai pembuktian dari hal sesuatu.

Hukum pembuktian sebagai bagian dari Hukum Acara Pidana yang mengatur macam-macam alat bukti yang sah menurut hukum, sistem yang

\footnotetext{
${ }^{29}$ Departemen Kehakiman RI, Pedoman Pelaksanaan Kitab Undang-Undang Hukum Acara Pidana (Departemen Kehakiman RI 1982).[1].

${ }^{30}$ M.Yahya Harahap, Pembahasan Permasalahan Dan Penerapan KUHAP: Pemeriksaan Sidang Pengadilan, Banding, Kasasi, Dan Peninjauan Kembali (Sinar Grafika 2002).[273].

${ }^{31}$ Andi Hamzah, Hukum Acara Pidana Indonesia (Sinar Grafika 2001).[9].

${ }^{32}$ Lilik Mulyadi, Putusan Hakim Dalam Hukum Acara Pidana: Teori, Praktik, Teknik Penyusunan Dan Permasalahannya (Citra Aditya Bakti 2007).[49-50].
} 
dianut dalam pembuktian, syarat - syarat dan tata cara yang mengajukan bukti tersebut serta kewenangan hakim untuk menerima, menolak dan menilai suatu pembuktian. Sumber-sumber hukum pembuktian adalah :

a. Undang-Undang;

b. Doktrin atau ajaran;

c. Yurisprudensi.

Dikaji dari perspektif sistem peradilan pidana pada umumnya dan hukum acara pidana (formeel strafrecht/strafprocessrecht) pada khususnya, aspek "pembuktian" memegang peranan menentukan untuk menyatakan kesalahan seseorang sehingga dijatuhkan pidana oleh hakim. Hakim saat menjatuhkan putusan, tidak hanya dalam bentuk pemidanaan, tetapi dapat juga menjatuhkan Putusan bebas dan Putusan lepas dari segala tuntutan hukum.

Putusan bebas akan dijatuhkan oleh hakim apabila Pengadilan (hakim) berpendapat bahwa dari hasil pemeriksaan di sidang pengadilan, kesalahan terdakwa atau perbuatan yang didakwakan kepadanya tidak terbukti secara sah dan meyakinkan. Putusan Lepas dari segala tuntutan hukum, akan dijatuhkan oleh hakim apabila berpendapat bahwa perbuatan yang didakwakan kepada terdakwa terbukti, tetapi perbuatan itu tidak merupakan suatu tindak pidana.

Tugas hakim didalam pertimbangan putusannya tidak hanya menentukan apa hukumnya bagi suatu fakta tertentu, melainkan juga norma hukum. Apabila untuk memecahkan suatu masalah tidak dijumpai aturan hukumnya, maka untuk pemecahan masalah tersebut harus dicari didalam doktrin hukum, dan nilai moral dengan mematuhi kode etik dan pedoman perilaku hakim. ${ }^{33}$ Oleh karena itu hakim di dalam memecahkan fakta yang ada dan akhirnya memutuskan sikap yang harus diambil yakni memberikan keadilan, sumber hukum seperti peraturan perundangundangan disamping, norma, doktrin, kebiasaan dan putusan pengadilan menjadi dasar reasoning dari putusannya.

Menurut, Yahya Harahap, SH. terdapat beberapa teori pembuktian dalam

\footnotetext{
${ }^{33}$ Marni Emmy Mustafa, 'Hubungan Antara Fakta, Norma, Moral Dan Doktrin Hukum Dalam Pertimbangan Putusan Hakim' <www.pt-jabar.go.id>.[2-3].
} 
hukum acara, yaitu $:^{34}$

1. Conviction-in Time.

Sistem pembuktian conviction-in time menentukan keyakinan hakim yang menentukan keterbuktian kesalahan terdakwa, yakni dari mana hakim menarik dan menyimpulkan salah tidaknya seorang terdakwa, yakni d ari mana hakim menarik dan menyimpulkan keyakinannya, tidak menjadi masalah dalam sistem ini. Keyakinan boleh diambil dan disimpulkan hakim dari alat-alat bukti yang diperiksanya dalam sidang pengadilan.

2. Onviction-Raisonee

Sistem conviction-raisonee pun, keyakinan hakim tetap memegang peranan penting dalam menentukan salah tidaknya terdakwa. Akan tetapi, pada sistem ini, faktor keyakinan hakim dibatasi. Jika dalam sistem pembuktian conviction-in time peran keyakinan hakim leluasa tanpa batas maka pada sistem conviction-raisonee, keyakinan hakim harus didukung dengan alasan- alasan yang jelas.

3. Pembuktian menurut Undang-undang secara positif (positief wettelijke stelsel)

Sistem ini berpedoman pada prinsip pembuktian dengan alat-alat bukti yang ditentukan undang-undang, yakni untuk membuktikan salah atau tidaknya terdakwa semata-mata digantungkan kepada alat-alat bukti yang sah. Terpenuhinya syarat dan ketentuan pembuktian menurut undang-undang, sudah cukup menentukan kesalahan terdakwa tanpa mempersoalkan keyakinan h akim, yakni apakah hakim yakin atau tidak tentang kesalahan terdakwa, buk an menjadi masalah.

4. Pembuktian menurut undang-undang secara negative (negatief wettelijke stelsel)

Sistem pembuktian menurut undang-undang secara negatif merupakan teori antara sistem pembuktian menurut undang-undang secara positif dengan sistem pembuktian menurut keyakinan atau conviction-in time. Sistem ini memadukan unsurobjektif dan subjektif dalam menentukan salah 
atau tidaknya terdakwa, tidak ada yang paling dominan diantara kedua unsur tersebut. ${ }^{35}$

Terdakwa dapat dinyatakan bersalah apabila kesalahan yang didakwakan kepadanya dapat dibuktikan dengan cara dan dengan alat-alat bukti yang sah menurut undang-undang serta sekaligus keterbuktian kesalahan itu "dibarengi" dengan keyakinan hakim.

Menurut M. Yahya Harahap, untuk menentukan salah atau tidaknya seorang terdakwa menurut sistem pembuktian undang-undang secara negatif, terdapat dua komponen: ${ }^{36}$

a. pembuktian harus dilakukan menurut cara dan dengan alat-alat bukti yang sah menurut undang-undang;

b. dan keyakinan hakim yang juga harus didasarkan atas cara dan dengan alatalat bukti yang sah menurut undang-undang.

Berdasarkan uraian di atas, maka dapat diartikan bahwa praktik pembuktian dalam proses peradilan yang diterapkan di Indonesia lebih cenderung pada sistem pembuktian menurut undang-undang secara positif, hal ini dikarenakan pada proses pemeriksaan di persidangan, hakim sering berpedoman pada alatalat bukti yang sah menurut undang-undang dalam menjatuhkan pidana kepada terdakwa.

\section{Alat bukti di dalam hukum acara pidana}

Pembuktian yang dianut Hukum Acara Pidana adalah system negatief menurut undang-undang (Negatif Wettelijk). Hal ini dapat dilihat di dalam Pasal 183 KUHAP : "Hakim tidak boleh menjatuhkan pidana kepada seorang kecuali apabila dengan sekurang-kurangnya dua alat bukti yang sah ia memperoleh keyakinan bahwa suatu tindak pidana benar-benar terjadi dan bahwa terdakwalah yang bersalah melakukannya".

${ }^{35}$ Waluyadi, Hukum Pembuktian Dalam Perkara Pidana Untuk Mahasiswa Dan Praktisi (Mandar Maju 2004).[39].

${ }^{36}$ M. Yahya Harahap, Op. Cit, [279]. 
Jadi pada pokoknya untuk dapat mempersalahkan seseorang terdakwa diharuskan adanya:

a. Keyakinan hakim;

b. Alat-alat pembuktian yang sah, bahwa benar telah terjadi perbuatan yang dapat dihukum dan orang yang dituduhlah yang melakukannnya.

Oleh karena itu, konsep keyakinan hakim tersebut baru dapat terbentuk dengan didasarkan pada adanya alat bukti yang sah menurut KUHAP. Keyakinan hakim yang akan terbentuk tersebut pada akhirnya nanti hanya terdiri dari dua macam, yaitu keyakinan bahwa terdakwa tidak. Berdasarkan Pasal 184 KUHAP, yang dimaksud dengan Alat bukti yang sah adalah:

a. Alat bukti yang sah ialah:

1) Keterangan saksi;

Bahwa di dalam Pasal 1 angka 26 Undang-Undang Nomor 8 Tahun 1981 Tentang Hukum Acara Pidana,berbunyi: "Saksi adalah orang yang dapat memberikan keterangan guna kepentingan penyidikan, penuntutan dan peradilan tentang suatu perkara pidana yang ia dengar sendiri, ia lihat sendiri dan ia alami sendiri”.

2) Keterangan ahli;

Berdasarkan Pasal 186 KUHAP, "Keterangan ahli ialah apa yang seorang ahli nyatakan di sidang pengadilan.” Keterangan ahli adalah suatu penghargaan dan kenyataan dan/atau kesimpulan atas penghargaan itu berdasarkan keahliannya. Apabila keterangan ahli diberikan pada tingkat penyidikan, maka sebelum memberikan keterangan, ahli harus mengucapkan sumpah atau janji terlebih dahulu. Akan tetapi, KUHAP tidak menyebut kriteria yang jelas tentang siapa itu ahli. Dengan perkembangan teknologi yang semakin pesat maka tidak terbatas banyaknya keahlian yang dapat memberikan keterangan sehingga pengungkapan perkara akan semakin terang, Seorang ahli umumnya mempunyai keahlian khusus di bidangnya baik formal maupun informal karena itu tidak perlu ditentukan adanya pendidikan formal, sepanjang 
sudah diakui tentang keahliannya. Hakimlah yang menentukan seorang itu sebagai ahli atau bukan melalui pertimbangan hukumnya. Keterangan ahli mempunyai visi apabila apa yang diterangkan haruslah mengenai segala sesuatu yang masuk dalam ruang lingkup keahliannya yang diterangkan mengenai keahliannya itu adalah berhubungan erat dengan perkara pidana yang sedang diperiksa.

3) Surat

Surat sebagaimana tersebut pada Pasal 184 ayat 1 huruf c, dibuat atas sumpah jabatan atau dikuatkan dengan sumpah, adalah:

a) berita acara dan surat lain dalam bentuk resmi yang dibuat oleh pejabat umum yang berwenang atau yang dibuat di hadapannya, yang memuat keterangan tentang kejadian atau keadaan yang didengar, dilihat atau yang dialaminya sendiri, d isertai d engan alasan yang jelas dan tegas tentang keterangannya itu;

b) surat yang dibuat menurut ketentuan p eraturan p erundang-undangan atau surat yang dibuat oleh pejabat mengenai hal yang termasuk dalam tata laksana yang menjadi tanggung jawabnya dan yang diperuntukkan bagi pembuktian sesuatu hal atau sesuatu keadaan;

c) surat keterangan dari seorang ahli yang memuat pendapat b erdasarkan k eahliannya mengenai sesuatu hal atau sesuatu keadaan yang diminta secara resmi dari padanya;

d) surat lain yang hanya dapat berlaku jika ada hubungannya dengan isi dari alat pembuktian yang lain.

4) Petunjuk;

Menurut Pasal 188 KUHAP, "Petunjuk adalah perbuatan, kejadian atau keadaan, yang karena persesuaiannya, baik antara yang satu dengan yang lain, maupun dengan tindak pidana itu sendiri, menandakan bahwa telah terjadi suatu tindak pidana dan siapa pelakunya." Petunjuk hanya dapat diperoleh dari :

a. Keterangan Saksi;

b. Keterangan Terdakwa;

c. Surat.

Penilaian atas kekuatan pembuktian dari suatu petunjuk dalam setiap keadaan tertentu dilakukan oleh hakim dengan arif lagi bijaksana 
setelah ia mengadakan pemeriksaan dengan penuh kecermatan dan kesaksamaan berdasarkan hati nuraninya.

5) Keterangan terdakwa;

Keterangan terdakwa ialah apa yang terdakwa nyatakan di sidang tentang perbuatan yang ia lakukan atau yang ia ketahui sendiri atau alami sendiri. Keterangan terdakwa yang diberikan di luar sidang dapat digunakan untuk membantu menemukan bukti di sidang, yakni sebagai alat bukti petunjuk asalkan keterangan itu didukung oleh suatu alat bukti yang sah sepanjang mengenai hal yang didakwakan kepadanya. Keterangan terdakwa hanya dapat digunakan terhadap dirinya sendiri. Keterangan terdakwa saja tidak cukup untuk membuktikan bahwa ia bersalah melakukan perbuatan yang didakwakan kepadanya, melainkan harus disertai dengan alat bukti yang lain.

b. Hal yang secara umum sudah diketahui tidak perlu dibuktikan.

Dengan demikian, untuk dapat menjatuhkan pemidanaan kepada seseorang haruslah terdapat minimal dua alat bukti dari lima alat bukti yang diatur dalam Pasal 184 KUHAP yang mengatur secara limitatif alat bukti yang sah menurut undang-undang. Hal tersebut diatas, juga mengisyaratkan bahwa KUHAP juga menganut prinsip Batas Minimum Pembuktian yang mengatur batas tentang keharusan yang dipenuhi dalam membuktikan kesalahan terdakwa.

\section{B. Pembuktian Penganjur Pembunuhan Anak.}

Penganjuran melakukan Tindak Pidana sebagaimana telah disampaikan diatas, termasuk dalam bentuk penyertaan dalam rumusan Pasal 55 KUHP, bentuk penyertaan ini sama halnya dengan menyuruh lakukan (doen pleger). Dalam bentuk menganjurkan pelakunya paling sedikit ada dua orang atau lebih dan kedudukannya masing-masing terdapat dua pihak yaitu, sebagai pihak yang menganjurkan dan pihak yang melakukan anjuran. Hanya saja yang melakukan anjuran penganjur bukan sebagai alat (instrument) yang tidak dapat dimintakan p ertanggungjawaban 
tetapi orang yang melakukan anjuran disini dapat dihukum atau dimintakan pertanggungjawabannya.

Dalam hal tidak adanya pihak penganjur maka antara pelaku atau orang yang berbuat tidak memiliki hubungan atau ikatan satu dengan yang lainnya, tetapi terpisah. Kedudukan pelaku dan pertanggungjawaban disesuaikan dengan kontribusi perbuatan yang dilakukan masing-masing pelaku. Jadi pada bentuk penyertaan ini kedudukkan antar pelaku baik yang menganjur atau yang dianjur melakukan sama-sama sebagai pelaku perbuatan pidana, dan diantara keduanya tidak ada hubungan yang mengikat pada waktu pelaksanaan perbuatan tidak seperti turut serta melakukan.

Hubungan antara kedua terjadi yaitu pada saat sebelum perbuatan pidana dilakukan. Sama halnya dengan menyuruh melakukan hanya saja dalam menyuruh melakukan dimana yang disuruh pelaku berada dibawah kendali yang menyuruh dan hal ini berbeda dengan menganjur lakukan karena penganjur memiliki peranan yang sangat terbatas yaitu sebatas menganjurkan saja. Pembunuhan anak dikualifikasikan sebagai kejahatan, baik anak yang masih dalam kandungan dan anak yang sudah dilahirkan. Didalam undang-undang tindak pidana pembunuhan anak disebut sebagai kindersdoodslag yang mana diatur dalam Pasal 341-343KUHP.

Bahwa untuk dapat disebut sebagai suatu pembunuhan anak, niat dari pelaku untuk menghilangkan nyawa anaknya harus timbul pada waktu atau segera setelah ia melahirkan anaknya, sebab apabila niat untuk menghilangkan nyawa anaknya itu telah timbil sebelum ia melahirkan anaknya, maka pembunuhan yang dilakukan oleh seorang ibu terhadap anaknya yang baru lahir itu bukan lagi merupakan suatu pembunuhan anak biasa, namun berencana. Dalam menjerat pelaku dengan pasal ini perbuatan pelaku harus memenuhi unsur-unsur dari Pasal 341 KUHP atau unsur Pasal 342 KUHP.

Bahwa dalam pembunuhan anak yang dilakukan oleh seorang ibu, perlulah ditarik latar belakang mengapa seorang ibu tega membunuh anaknya. Dimana adakalanya peran seorang ibu pelaku pembunuhan anak tersebut dilakukan dikarenakan suatu anjuran baik oleh pacar ibu, atau orang tua, ataupun orang lain 
yang kemudian atas adanya saran atau anjurann orang-orang tersebut si ibu tega membunuh bayinya. Dapat diketahuinya adanya keterlibatan orang lain dalam memberikan masukan kepada pelaku untuk membunuh bayinya, diketahui dari pengakuan pelaku baik yang diungkapkan saat pemeriksaan tersangka ataupun saat pemeriksaan terdakwa.

Pengakuan yang diungkapkan oleh pelaku dapat digunakan sebagai alat bukti petunjuk, yang dapat bernilai pembuktian asalkan pengakuan tersebut didukung dengan alat bukti lain.

Di dalam Pasal 55 ayat 1 ke-2 KUHP, Konsep pengajur dapat dikategorikan sebagai mereka yang dengan memberi atau menjanjikan sesuatu dengan menyalahgunakan kekuasaan atau martabat, dengan kekerasan, ancaman atau penyesatan, atau dengan memberi kesempatan, sarana atau keterangan, sengaja menganjurkan orang lain supaya melakukan perbuatan.

Untuk dapat terpenuhinya sebagai penganjur unsur dari Pasal 55 ayat 1 ke-2 KUHP, haruslah dipenuhi:

1. Mereka yang dengan memberi atau menjanjikan sesuatu;

2. Dengan menyalahgunakan kekuasaan atau martabat, dengan kekerasan; ancaman atau penyesatan, atau dengan memberi kesempatan, sarana atau keterangan;

3. Sengaja menganjurkan orang lain supaya melakukan perbuatan.

Berbeda dengan orang yang turut melakukan, R. Soesilo menjelaskan mengenai apa yang dimaksud dengan "orang yang turut melakukan" (medepleger) dalam Pasal 55 KUHP. Menurut R. Soesilo, “turut melakukan” dalam arti kata "bersamasama melakukan”. Sedikit-dikitnya harus ada dua orang, ialah o rang yang melakukan (pleger) dan o rang yang turut melakukan (medepleger) peristiwa pidana. Di sini diminta bahwa kedua orang itu semuanya melakukan perbuatan pelaksanaan, jadi melakukan anasir atau elemen dari peristiwa tindak pidana itu. Tidak boleh misalnya hanya melakukan perbuatan persiapan saja atau perbuatan yang sifatnya h anya menolong, sebab jika demikian, maka or ang yang menolong itu tidak masuk "medepleger" akan tetapi dihukum sebagai 
"membantu melakukan" (medeplichtige) dalam Pasal 56 KUHP. ${ }^{37}$

Bahwa berdasarkan teori subjektivitas, ada dua ukuran yang dipergunakan: Ukuran kesatu adalah mengenai wujud kesengajaan yang ada pada di pelaku, sedangkan ukuran kedua adalah mengenai kepentingan dan tujuan dari pelaku. Ukuran kesengajaan dapat berupa:

1) Soal kehendak si pelaku untuk benar-benar turut melakukan tindak pidana, atau hanya untuk memberikan bantuan; atau

2) Soal kehendak si pelaku untuk benar-benar mencapai akibat yang merupakan unsur dari tindak pidana, atau hanya turut berbuat atau membantu apabila pelaku utama menghendakinya.

Sedangkan, ukuran mengenai kepentingan atau tujuan yang sama yaitu apabila si pelaku ada kepentingan sendiri atau tujuan sendiri, atau hanya membantu untuk memenuhi kepentingan atau untuk mencapai tujuan dari pelaku utama.

Berdasarkan uraian di atas kiranya dapat kita simpulkan dari "turut melakukan" tindak pidana. Dalam "turut melakukan" ada kerja sama yang disadari antara para pelaku dan mereka bersama-sama melaksanakan kehendak tersebut, para pelaku memiliki tujuan dalam melakukan tindak pidana tersebut. Bahwa orang yang membujuk tersebut harus sengaja membujuk orang lain, sedang membujuknya harus memakai salah satu dari jalan-jalan seperti pemberian, salah memakai kekuasaan dan sebagainya yang disebutkan dalam pasal itu, artinya tidak boleh memakai jalan lain. Dalam "membujuk melakukan", orang yang dibujuk dapat dihukum juga sebagai "pleger" atau orang yang melakukan tindak pidana. Akan tetapi, menurut Pasal 55 ayat 2 KUHP, pertanggungjawaban pembujuk dibatasi hanya sampai pada apa yang dibujuknya untuk dilakukan serta akibatnya.

Sehingga terhadap kekasih pelaku, keluarga pelaku atau teman pelaku dapat dikenakan penganjur pembunuhan anak, asalkan dapat dibuktikan bentuk anjurannya tersebut sebagaimana Pasal 55 ayat 1 ke-2 KUHP yang dikaitkan dengan

${ }^{37}$ R. Soesilo, Kitab Undang-Undang Hukum Pidana (KUHP) Serta Kometar- Kometarnya Lengkap Pasal Demi Pasal (Politeia 1995).[73]. 
alat bukti. Atas adanya pengakuan dari pelaku pembunuhan anak yang menerangkan adanya penganjur dalam tindak pidana yang dilakukannya, Kepolisian berwenang menentukan tindakan apa yang akan diambil terhadap kejahatan tersebut artinya Kepolisian berhak untuk menangani atau tidak menangani. Apabila telah cukup bukti untuk menjerat pelaku penganjur pembunuhan anak, maka Kepolisian memilih untuk meneruskan penanganan perkara tersebut, maka berkas akan dilimpahkan ke Kejakasaan untuk dilakukan penelitian dapat tidaknya perkara tersebut dilakukan penuntutan atau tidak. Apabila dapat dilakukan penuntutan, maka berkas dilimpahkan ke Pengadilan namun apabila belum memenuhi unsur pasal yang dibuktikan maka berkas perkara dikembalikan kepada penyidik Kepolisian.

\section{Kendala Pembuktian Penganjur Pembunuhan Anak.}

Untuk pembuktian Penganjur Pembunuhan anak, terdapat beberapa kesulitan. Hal ini dikarenakan sulitnya membuktikan orang yang sengaja menganjurkan (pembuat penganjur: uitlokker/aktor intelektualis). Dimana Ada lima syarat dari seorang pembuat penganjur:

1. Kesengajaan si pembuat penganjur yang harus ditujukan pada 4 hal:

a. ditujukan pada digunakannya upaya-upaya penganjuran;

b. ditujukan pada mewujudkan perbuatan menganjurkan beserta akibatnya;

c. ditujukan pada orang lain untuk melakukan perbuatan (apa yang dianjurkan);

d. ditujukan pada orang lain yang mampu bertanggung jawab atau dapat dipidana.

2. Dalam melakukan perbuatan menganjurkan harus menggunakan cara-cara menganjurkan sebagaimana Pasal 55 ayat 1 ke 2 KUHP;

3. Terbentuknya kehendak orang yang dianjurkan (pembuat pelaksananya) untuk meakukan tindak pidana sesuai dengan apa yang dianjurkan adalah disebabkan langsung oleh digunakannya upaya-upaya penganjuran oleh si pembuat penganjur;

4. Orang yang dianjurkan (pembuat pelaksanaanya) telah melaksanakan tindak pidana sesuai dengan yang dianjurkan;

5. Orang yang dianjurkan adalah orang yang memiliki kemampuan bertanggung jawab.

Dalam membuktikan seorang penganjur pembunuhan anak adalah, sesuai dengan penerapan sistem pembuktian yang dianut dalam KUHAP yang menggunakann sistem pembuktian secara negatif,sebagaimana Pasal 183 KUHAP 
yaitu bersalah atau tidaknya ditentukan oleh keyakinan hakim berdasarkan minimal 2 alat bukti yang sah.

Adapun kendala dalam pembuktian penganjur pembunuhan anak, minimnya saksi yang mengetahui tentang keterlibatan pelaku dalam menganurkan seorang ibu untuk melakukan tindak pidana pembunuhan anak, karena satu saksi bukanlah saksi "Unus Testis Nullus Testis" merupakan asas yang menolak kesaksian dari satu orang saksi saja. Dalam hukum acara pidana, keterangan seorang saksi saja tanpa dukungan alat bukti lain tidak boleh dipercaya atau tidak dapat digunakan sebagai dasar pembuktian dipersidangan. Prinsip ini secara tegas dianut oleh KUHAP dalam pembuktian vide Pasal 185 ayat 2.

Bertitik tolak dari ketentuan pasal 185 ayat 2 KUHAP, keterangan seorang saksi saja belum dianggap sebagai suatu alat bukti yang cukup untuk membuktikan kesalahan terdakwa/ pelaku penganjur pembunuhan anak (unus testis nullus testis). Ini berarti jika alat bukti yang dikemukakan penuntut umum yang terdiri dari seorang saksi saja tanpa ditambah dengan keterangan saksi yang lain atau alat bukti yang lain, kesaksian tunggal seperti ini tidak dapat dinilai sebagai alat bukti yang cukup untuk membuktikan kesalahan terdakwa sehubungan dengan tindak pidana yang didakwakan kepadanya.

Namun apabila pelaku penganjur pembunuhan anak mengaku kesalahan yang didakwakan kepadanya, dalam hal ini seorang saksi saja sudah dapat membuktikan kesalahan terdakwa. Karena selain keterangan seorang saksi tadi, juga telah dicukupi dengan alat bukti keterangan terdakwa. Akhirnya telah terpenuhi ketentuan minimum pembuktian yakni keterangan saksi dan keterangan terdakwa.

\section{Kesimpulan}

Penganjur tindak pidana sebagai suatu tindak kejahatan, maka untuk dikategorikan sebagai penganjur, seseorang harus memenuhi 2 (dua) syarat, yaitu pertama adanya niat dan yang kedua ada kehendak menggerakkan orang lain untuk melakukan perbuatan tertentu yang dimaksud oleh penganjur. Oleh karena itu anjuran penganjur harus tegas dan jelas sehingga dapat ditafsirkan oleh pelaku untuk 
melakukan suatu perbuatan tindak pidana. Suatu perbuatan dikualifikasi sebagai pengajuran apabila menggunakan sarana-sarana sebagaimana tersebut dalam Pasal 55 ayat 1 ke 2 KUHP, yakni memberikan sesuatu, menjanjikan sesuatu, menyalahgunakan kekuasaan atau martabat, dengan kekerasan, ancaman atau penyesatan, atau dengan memberi kesempatan, sarana atau keterangan. Dimana penganjur pembunuhan anak bukan dituntut karena pembunuhan anak melainkan karena keikutsertaannya. Sehingga terhadap pengganjur pembunuhan anak dapat dikenakan pembunuhan anak atas apa yang dianjurkannya sebagaimana Pasal 343 KUHP.

Penganjur dapat juga dikenakan suatu tindak pidana penganjuran pembunuhan anak jika dapat dibuktikan dia dengan sengaja menganjurkan seseorang untuk melakukan suatu tindak pidana pembunuhan anak. Dengan demikian, baik penganjur maupun yang menerima anjuran, harus dicari pertanggungjawaban masing-masing orang yang tersangkut dalam tindak pidana tersebut. Kedudukan pelaku dan pertanggungjawaban disesuaikan dengan kontribusi perbuatan yang dilakukan masing-masing pelaku. Terhadap penganjur tersebut hanya dapat dipertanggungjawabkan untuk perbuatan yang dapat dihukum yang ia anjurkan dikaitkan dengan rangkaian peristiwa yang dapat dibuktikan, yang mana perlu didukung dengan pemenuhan alat bukti sebagaimana Pasal 184 KUHAP, yakni: keterangan saksi, keterangan ahli, surat, petunjuk dan keterangan terdakwa.

\section{Daftar Bacaan}

\section{Buku}

Andrisman T, Hukum Pidana Asas-Asas Dan Dasar Aturan Umum Hukum Pidana Indonesia (Universitas Lampung 2009).

Chazawi A, Pelajaran Hukum Pidana: Stelsel Pidana, Tindak Pidana, TeoriTeori Pemidanaan Dan Batas Berlakunya Hukum Pidana (Raja Grafindo Persada 2005).

Effendi E, Hukum Pidana Indonesia (Refika Aditama 2011).

Hamzah A, Hukum Acara Pidana Indonesia (Sinar Grafika 2001).

Hartanti E, Tindak Pidana Korupsi (Sinar Grafika 2005). 
Huda C, Dari Tiada Pidana Tanpa Kesalahan Menuju Kepada Tiada Pertanggungjawaban Pidana Tanpa Kesalahan: Tinjauan Kritis Terhadap Teori Pemisahan Tindak Pidana Dan Perrtanggungjawaban Pidana (Cetakan I, Kencana 2006).

Kartanegara S, Hukum Pidana Kumpulan Kuliah Bagian Satu (Balai Lektur Mahasiswa).

Lamintang, Dasar-Dasar Hukum Pidana Indonesia (Sinar Grafika).

Lilik Mulyadi, Putusan Hakim Dalam Hukum Acara Pidana: Teori, Praktik, Teknik Penyusunan Dan Permasalahannya (Citra Aditya Bakti 2007).

M.Yahya Harahap, Pembahasan Permasalahan Dan Penerapan KUHAP: Pemeriksaan Sidang Pengadilan, Banding, Kasasi, Dan Peninjauan Kembali (Sinar Grafika 2002).

Moeljatno, Hukum Pidana Delik-Delik Penyertaan (Bina Aksara 1983).

—_, Pengantar Ilmu Hukum Pidana (1983).

—_, Azaz-Azaz Hukum Pidana (Modul untuk Diklat Pendidikan dan Pelatihan Pembentukan Jaksa (PPPJ) 2010).

Aruan Sakidjo dan Bambang Poernomo, Hukum Pidana Dasar Aturan Umum Hukum Pidana Kodifikasi (Ghalia Indonesia 1990).

Prodjodikoro Wirjono, Asas-Asas Hukum Pidana Di Indonesia (PT Eresco 2000).

R. Soesilo, Kitab Undang-Undang Hukum Pidana (KUHP) Serta KomentarKomentarnya Lengkap Pasal Demi Pasal (Politeia 1995).

RI DK, Pedoman Pelaksanaan Kitab Undang-Undang Hukum Acara Pidana (Departemen Kehakiman RI 1982).

Roeslan Saleh, Perbuatan Pidana Dan Pertanggung Jawaban Pidana (Aksara Baru 1981).

__, Sifat Melawan Hukum Dari Perbuatan Pidana (Aksara Baru 1981).

Samudera T, Hukum Pembuktian Dalam Acara Perdata (PT Alumni 2004).

Waluyadi, Hukum Pembuktian Dalam Perkara Pidana Untuk Mahasiswa Dan Praktisi (Mandar Maju 2004).

Wisnubroto A, Teknis Persidangan Pidana (Universitas Atma Jaya 2009). 


\section{Laman}

Marni Emmy Mustafa, 'Hubungan Antara Fakta, Norma, Moral Dan Doktrin Hukum Dalam Pertimbangan Putusan Hakim'<www.pt-jabar.go.id $>$.

HOW TO CITE: Irene Ulfa, ‘Pembuktian Penganjur Dalam Tindak Pidana Pembunuhan Anak’ (2018) Vol. 01 No. 2 Media Iuris. 